\title{
Predatory midges of the tribes Palpomyiini and Sphaeromiini (Diptera: Ceratopogonidae) from the Middle East, with keys and descriptions of new species
}

\author{
Alicja ALWIN-KOWNACKA ${ }^{1, *}$, Ryszard SZADZIEWSKI ${ }^{2}$ \& Jacek SZWEDO ${ }^{3}$ \\ Department of Invertebrate Zoology and Parasitology, University of Gdańsk, \\ 59, Wita Stwosza Street, PL80-308, Poland. \\ *Corresponding author: alicja.alwin@biol.ug.edu.pl \\ ${ }^{2}$ Email: ryszard.szadziewski@biol.ug.edu.pl \\ ${ }^{3}$ Email: jacek.szwedo@biol.ug.edu.pl \\ ${ }^{1}$ urn:1sid:zoobank.org:author:0995CC31-5CC8-46F3-BB72-A4D76919750A \\ ${ }^{2}$ urn:lsid:zoobank.org:author:083FF55D-C4C0-4C7D-AE23-562619624664 \\ ${ }^{3}$ urn:lsid:zoobank.org:author:36BAE161-ECCD-4D89-B383-C7CC84FF0A89
}

\begin{abstract}
The Middle East biting midges of the tribes Palpomyiini (20 species in three genera) and Sphaeromiini s. lat. (six species in five genera) are reviewed. Three new species are described and illustrated: Bezzia libanensis Alwin \& Szadziewski sp. nov., B. sharjahi Alwin \& Szadziewski sp. nov. and Palpomyia freidbergi Alwin \& Szadziewski sp. nov. Bezzia aegyptia Kieffer, 1925 is recognized as a new junior synonym of $B$. albicornis (Meigen, 1818) (syn. nov.) and B. omanensis Boorman \& van Harten, 2002, is recognized as a junior synonym of B. (Sivabezzia) pachypyga Remm, 1974 (syn. nov.). Keys to the genera and species of the tribes Palpomyiini and Sphaeromiini of the Middle East are also provided.
\end{abstract}

Keywords. Bezzia, Palpomyia, new synonymy, Middle East, distribution.

Alwin-Kownacka A., Szadziewski R. \& Szwedo J. 2017. Predatory midges of the tribes Palpomyiini and Sphaeromiini (Diptera: Ceratopogonidae) from the Middle East, with keys and descriptions of new species. European Journal of Taxonomy 318: 1-30. https://doi.org/10.5852/ejt.2017.318

\section{Introduction}

In our first article in a series on Ceratopogonidae of the Middle East, all faunistic studies on the family were reviewed, and keys for identification of subfamilies and tribes were provided (Alwin et al. 2016). In that article, we also included diagnoses and keys to the seven genera and 22 species of the tribe Ceratopogonini in this region (Alwin et al. 2016). Herein, we provide faunistic and taxonomic summaries of species of two other predaceous tribes (Palpomyiini and Sphaeromiini) that inhabit the Middle East.

The Middle East fauna of the tribe Palpomyiini is rich and includes 18 recorded species in the genera Bezzia Kieffer, 1899, Palpomyia Meigen, 1818 and Phaenobezzia Haeselbarth, 1965. These three genera 
include 629 species worldwide (Borkent 2016). Conversely, the tribe Sphaeromiini includes only six species and five genera in the Middle East: Homohelea Kieffer, 1917, Johannsenomyia Malloch, 1915, Macropeza Meigen, 1818, Nilobezzia Kieffer, 1921 and Sphaeromias Curtis, 1829. These five genera contain 172 extant species worldwide (Borkent 2016).

\section{Material and methods}

Specimens were collected in Israel, Lebanon, the United Arab Emirates and Yemen, then subsequently dissected, mounted on microscope slides in Canada balsam and studied as described by Alwin et al. (2016).

Holotypes, paratypes and other specimens are deposited in the Department of Invertebrate Zoology \& Parasitology, University of Gdańsk, Poland (CEIUG) and the Department of Zoology, Tel Aviv University, Israel (TAU).

\section{Results}

Class Insecta Linnaeus, 1758

Order Diptera Linnaeus, 1758

Family Ceratopogonidae Newman, 1834

Subfamily Ceratopogoninae Newman, 1834

Tribe Palpomyiini Enderlein, 1936

\section{Key to genera of Middle East Palpomyiini}

1. Wing with two radial cells Palpomyia Meigen, 1818

- Wing with one radial cell

2. Female fifth tarsomeres armed with stout ventral setae with sharp, bent tips; gonostylus of male genitalia greatly reduced in size or absent.....

Phaenobezzia Haeselbarth, 1965

- Female fifth tarsomeres usually unarmed (some species in the subgenus Homobezzia have 2 partial ventrolateral rows of setae); gonostylus of male genitalia well developed Bezzia Kieffer, 1899

Genus Bezzia Kieffer, 1899

\section{Type species}

Ceratopogon ornatus Meigen, 1830; by original designation.

\section{Diagnosis}

Body nearly bare, with robust thorax. Wing with 1 radial cell; membrane without macrotrichia. Legs slender; fore femur with 0-12 ventral spines, mid and hind femora sometimes with ventral spines; fourth tarsomeres short, more or less cordiform; fifth tarsomeres of female without ventral batonnets; female claws simple, equal-sized, usually with small inner tooth. Female abdomen with paired internal tergal apodemes and usually 2 seminal capsules. Male genitalia with short tergite IX; parameres fused, usually rod-like but sometimes variable in shape; gonostylus well developed (de Meillon \& Wirth 1991).

\section{Key to males of subgenera of Middle East Bezzia}

1. Aedeagus shield-shaped, with slender, long submedian process (Fig. 3C) .2

- Aedeagus Y-shaped, without slender, long submedian process (Fig. 1J) 3 
ALWIN-KOWNACKA A. et al., Palpomyiini and Sphaeromiini biting midges from the Middle East

2. Gonocoxite elongate, slender; gonostylus short, divided into 3-4 tooth-like lobes

- Gonocoxite short, stout; gonostylus long, slender, not divided into lobes

Pygobezzia Remm, 1974

Sivabezzia Remm, 1974

3. Aedeagus bare; flagellomere 10 longer than 11 (Fig. 1C)

Bezzia Kieffer, 1899

- Aedeagus covered with short, spine-like setae; flagellomere 10 shorter than 11 (Fig. 2B)

Homobezzia Macfie, 1932

Subgenus Bezzia Kieffer, 1899

\section{Diagnosis}

Fore femur with or without ventral spines. Male flagellum with flagellomere 10 elongate, longer than distal segments 11-13. Male flagellar plume well developed. Male aedeagus without spicules on ventral membrane; gonostylus elongate, simple (Krzywiński 1995).

\section{Key to males of Bezzia (Bezzia) of the Middle East}

1. Fore femur with 1 or more ventral spines .2

- Fore femur without ventral spines 3

2. Hind femur and tibia uniformly brown; gonostylus with blunt apex

B. flavicornis (Staeger, 1839)

- Hind femur and tibia yellow, with brown subapical and subbasal bands; gonostylus with sharply pointed apex

B. naseri Boorman \& van Harten, 2002

3. Sternite IX of male genitalia very long; gonostylus with sharply pointed apex

B. libanensis Alwin \& Szadziewski sp. nov.

- Sternite IX of male genitalia short; gonostylus with blunt apex

B. mellori Boorman \& van Harten, 2002

\section{Bezzia (Bezzia) flavicornis (Staeger, 1839)}

Ceratopogon flavicornis Staeger, 1839: 599 ( $\hat{\jmath}, q$, Denmark).

Ceratopogon flavipalpis Winnertz, 1852: 80 (㝏, Germany).

Bezzia flavipluma Kieffer, 1919: 126 (ふ̋, Hungary).

Bezzia spinifera Goetghebuer, 1920: 106 (ฏึ, Belgium).

Bezzia spinosula Clastrier, 1962: 100 (ð, France).

Bezzia flavipalpis - Kieffer 1901: 153 (中, key).

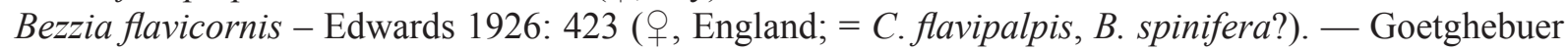
1934: 79 (9, key, distribution). - Remm 1988: 30 (distribution; = C. flavipalpis, B. flavipluma, B. spinifera, B. spinosula). - Krzywiński 1995: 138 (오, ô, Poland, Bulgaria, Switzerland, France, Denmark).

Bezzia spinifera - Zilahi-Sebess 1940: 106 (ð̊, Hungary).

\section{Diagnosis}

A large orange-brown species. Scutum and scutellum darker than remainder of thorax. Wing pale; wing length $2.20 \mathrm{~mm}$; costal ratio 0.80 . Palpus yellowish; palpal ratio 4.50 . Fore femur with $2-4$ ventral spines; fore and mid femora brownish; fore and mid tibiae brown with distinct yellow subapical band; hind femur and tibia dark brown; tarsi yellow, fith tarsomeres slightly darker; tarsal ratio of fore leg 2.10, 
of mid leg 2.20, of hind leg 2.00. Abdomen pale brown. Female with 2 large ovoid seminal capsules with short necks, one larger than the other. Male gonocoxite short, straight and thick; gonostylus short, simple, with blunt apex. Parameres fused, slightly expanded in middle, with V-shaped excavation on apical portion. Aedeagus Y-shaped, with long submedian process and blunt apex (Clastrier 1962; Krzywiński 1995).

\section{Material examined}

ISRAEL: 1 + , Baniass, 24 Apr. 1982, F. Kaplan leg. (TAU).

\section{Distribution}

Europe (Austria, Belarus, Belgium, Bulgaria, Czech Republic, Denmark, Estonia, France, Germany, Great Britain, Hungary, Latvia, Lithuania, Netherlands, Poland, Switzerland, Ukraine), central Russia, Azerbaijan and Kyrgyzstan (Remm 1988; Szadziewski et al. 2013). We provide the first record of this species from Israel.

Bezzia (Bezzia) libanensis Alwin-Kownacka \& Szadziewski sp. nov. urn:lsid:zoobank.org:act:B1B97EC8-DFA5-4537-BB13-FAC1B73487C6

Fig. 1

\section{Diagnosis}

A small dark brown species without fore femoral spines. The male genitalia are unique in having a greatly elongate sternite IX, with narrow V-shaped caudomedian cleft, and a Y-shaped aedeagus without ventral spicules and an abruptly tapered, sharply pointed apex. Female unknown.

\section{Etymology}

The specific name refers to the Latin name of Lebanon (Libanus), where the holotype was collected.

\section{Material examined}

Holotype

LEBANON: ${ }^{\curvearrowright}$, Fanar, $33^{\circ} 52.680^{\prime}$ N, $35^{\circ} 33.547^{\prime}$ E, 138 m a.s.l, at light, 6 May 2012, P. Dominiak leg. (CEIUG).

\section{Description}

\section{Male}

HEAD. Uniformly brown. Antenna (Fig. 1C) pale brown; flagellomeres 10-13 predominately dark brown; flagellomere 10 elongate, considerably longer than 11-13; total flagellum length $0.90 \mathrm{~mm}$; antennal ratio 0.70. Palpus slender, brownish; segment 3 slender with few sensilla capitata; palpal ratio 4.00.

Thorax (Fig. 1B). Dark brown. Wing (Fig. 1A) veins pale; 1 poorly marked elongate radial cell; wing length $1.30 \mathrm{~mm}$; costal ratio 0.60 . Halter brown. Legs (Figs. 1D-F) with brown coxae; all femora without ventral spines; fore and mid femora yellowish, proximal $1 / 2$ of venter brown and with subapical, apical dark brown bands; hind femur brown, with apical, subapical yellow bands; tibiae brown, with sub-basal, subapical yellow bands; tarsi yellow, with pale brown apices, tarsomeres 4-5 slightly darker than 1-3; tarsal ratio of fore leg 2.20, of mid leg 2.40, of hind leg 2.20.

Abdomen (Fig. 1G). Brown.

GenitaLia (Fig. 1G-J). Sternite IX heavily sclerotized, long, apex extending to mid-length of gonocoxites, with narrow, V-shaped caudomedian cleft. Tergite IX short, slender, with elongate cerci. Gonocoxite 

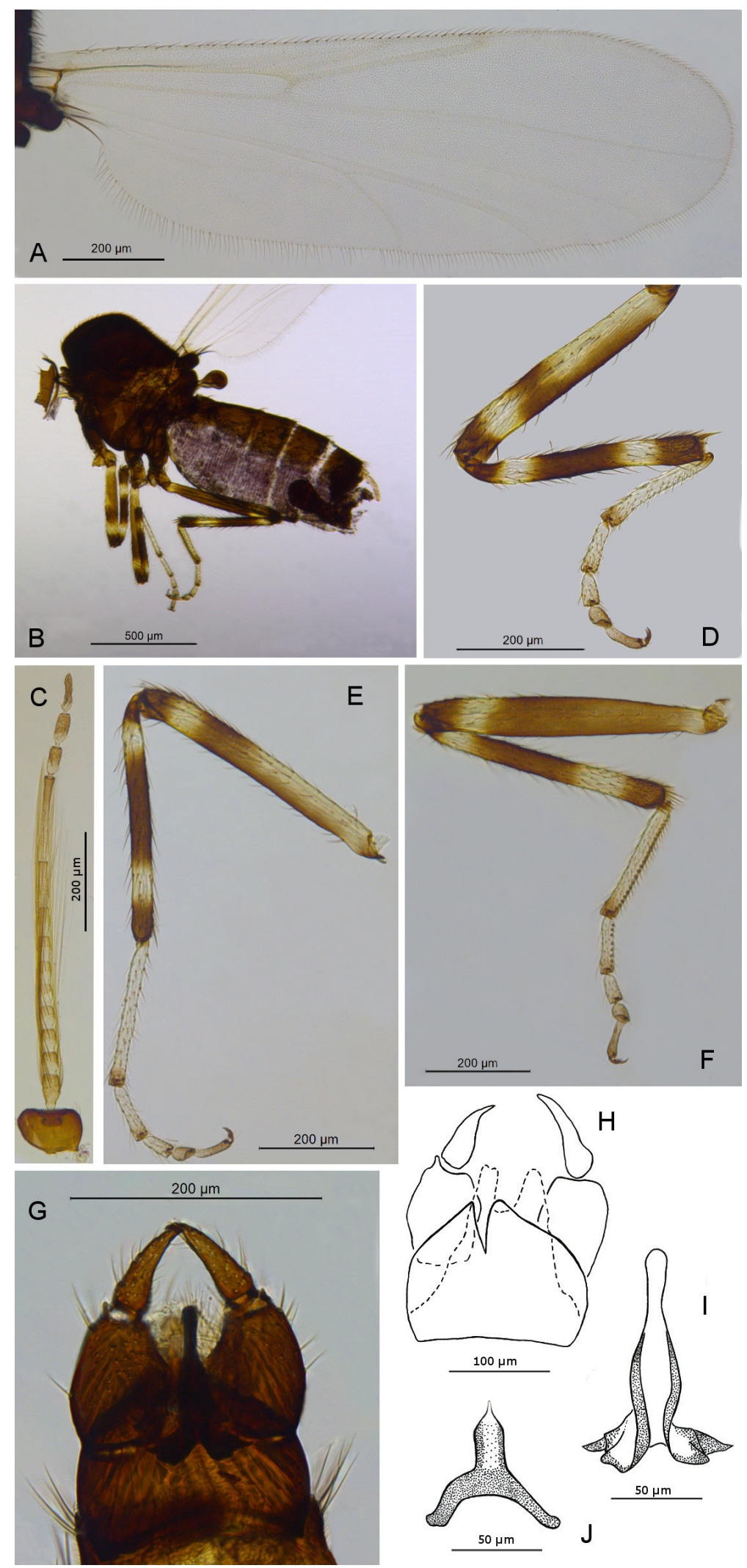

Fig. 1. Bezzia libanensis Alwin \& Szadziewski sp. nov., §ิ. A. Wing. B. Thorax. C. Antennal scape and flagellum. D. Fore leg. E. Mid leg. F. Hind leg. G. Male genitalia. H. Male genitalia, ventral view. I. Parameres. J. Aedeagus. 
short, stout; gonostylus moderately long, nearly straight, slightly curved distally, apex tapered, with pointed tip. Parameres (Fig. 1I) fused, rod-like; basal arms short, broad, bifurcate with unequal-length prongs; distal portion slightly vasiform, with heavily sclerotized margins, apical $1 / 3$ narrower, more lightly sclerotized, with rounded tip. Aedeagus (Fig. 1J) with bare ventral membrane; basal arms broad, heavily sclerotized; basal arch curved, extending $1 / 3$ of total aedeagus length; distal portion short, margin heavily sclerotized, with sharply pointed apex.

\section{Female}

Unknown.

\section{Distribution}

Lebanon; known only from the type locality.

\section{Remarks}

The male antennal flagellum of this new species has an elongate flagellomere 10 and a bare aedeagus, characters typical of members of the subgenus Bezzia. This new species differs from all other Palearctic and Afrotropical members of the genus by its greatly elongate sternite IX, which extends to the midlength of the gonocoxites and covers their bases.

Bezzia (Bezzia) mellori Boorman \& van Harten, 2002

Bezzia mellori Boorman \& van Harten, 2002: 456 (ð, figure, description, Oman).

\section{Diagnosis}

An orange-brown species. Scutum with darker band on lateral sides, humeral areas paler. Legs pale; femorotibial joints darker; femora unarmed; fore femur with darker dorsal central area near apex; mid femur with narrow, darker dorsal area on apical portion; hind femur and tibiae with vague indications of similar markings. Male genitalia with rather long gonocoxite and short, blunt gonostylus; parameres fused, slender with broad base and expanded slender, triangular, with blunt appendix and high basal arch (Boorman \& van Harten 2002).

\section{Distribution}

Oman.

Bezzia (Bezzia) naseri Boorman \& van Harten, 2002

Bezzia naseri Boorman \& van Harten, 2002: 457 (ð, figure, description, Yemen).

\section{Diagnosis}

Scutum dark brown, scutellum paler. Legs yellowish, with brown bands; fore femur with faint dark band at apical $2 / 3$; fore and mid tibiae with dark bands at/near proximal $1 / 3$ and apex; mid femur with a single dark apical band; hind femur and tibia with wide dark sub-basal and subapical bands; fore femur armed with 2 spines. Male genitalia short, with long, evenly curved gonostylus, with pointed apical portion; parameres fused, with low basal arch, distal portion moderately stout, apex with 2 bifid pointed divergent processes; aedeagus slender, with broad base, low basal arch and blunt apex (Boorman \& van Harten 2002).

\section{Distribution}

Yemen. 
ALWIN-KOWNACKA A. et al., Palpomyiini and Sphaeromiini biting midges from the Middle East

Subgenus Homobezzia Macfie, 1932

\section{Type species}

Homobezzia nyasae Macfie, 1932; by original designation.

\section{Diagnosis}

Fore femur with or without ventral spines (all Middle East species with fore femoral spines). Male flagellomere 10 shorter than 11; flagellar plume poorly developed. Male aedeagus covered with fine setae on ventral surface; gonostylus elongate (Krzywiński 1995).

\section{Key to males of Bezzia (Homobezzia) of the Middle East}

1. Legs pale yellow, with dark bands; submedian process of male parameres straight

B. kuhetiensis Remm, 1967

- Legs pale brown, without dark bands; submedian process of male parameres slightly curved ventrally B. sharjahi Alwin \& Szadziewski sp. nov.

\section{Bezzia (Homobezzia) kuhetiensis Remm, 1967}

Bezzia kuhetiensis Remm, 1967: 33 (ð̊, o, Azerbaijan).

Bezzia kuhetiensis - Turgut \& Kilic 2015: 14 (†, record, Turkey).

\section{Diagnosis}

Thorax brown, scutellum paler. Head brown. Palpus yellow. Flagellomeres 1-8 yellow, 9-13 brown on distal portions. Femora pale yellow or white, with dark brown band on apex; fore femur with small smoky area near apex, with 2 ventral spines; tibiae white, with dark brown bands on apical and basal portions; fore tibia with another dark brown band on middle portion; tarsomeres white, with darker apices. Wing pale. Abdomen pale brown. Female with 2 round seminal capsules with long, thick necks. Male genitalia with long tergite IX; gonocoxite stout, moderately short, slender, curved and gonostylus with sharply pointed apex; parameres fused, base W-shaped, with long, straight, slender distal process; aedeagus triangular, slender, with low basal arch and barely visible rounded apex (Remm 1967).

\section{Distribution}

Azerbaijan, Ukraine (Remm 1988). In the Middle East recorded from Turkey (Turgut \& Kilic 2015).

Bezzia (Homobezzia) sharjahi Alwin-Kownacka \& Szadziewski sp. nov. urn:lsid:zoobank.org:act:07610F8D-C955-4FD8-851A-395BA06AFB87

Fig. 2

\section{Diagnosis}

This new species differs from all other Middle East congeners in having the following combination of characters: thorax orange-brown with distinctly paler scutellum; legs uniformly brownish; fore femur with 6-9 ventral spines; male gonostylus long, with pointed apex; parameres long, slender, slightly curved dorsally; female with 2 subspherical seminal capsules with very long necks.

\section{Etymology}

The specific name refers to the Sharjah Desert, where most of the type series was collected. 


\section{Material examined}

Holotype

UNITED ARAB EMIRATES: đ̊ adult, Sharjah Desert Park, 18 Jan. 2005, A. van Harten leg. (CEIUG).

\section{Paratypes}

UNITED ARAB EMIRATES: 3 + $\odot, 3 \hat{\jmath}$, same collection data as holotype except 18-25 Jan. 2005, light trap; 3 우, 1 ऽ , same collection data except 9 Mar. 2005; 1 , same collection data except 30 Apr. 2005; 1 + , same collection data except 30 Jun. 2005; 1 q , 1 §, same collection data except 21 Jul. 2005; 1 \&, Wadi Wurayah, light trap, 15 Jan.-22 Feb. 2009, A. van Harten leg. (CEIUG).

YEMEN: 2 q , Al Mukalla, light trap, 1. Feb. 2003, A. van Harten leg. (CEIUG).

\section{Description}

Male

HEAD. Uniformly pale brown. Antenna (Fig. 2B) pale brown; flagellar plume poorly developed; flagellomeres 2(3)-13 with paler basal halves; flagellomeres 10-13 short; total flagellum length 0.50 $0.70 \mathrm{~mm}$; antennal ratio $0.50-0.70$. Palpus yellow, slender; third palpal segment short, with distinct capitate sensilla; palpal ratio 2.00 .

THorax. Orange-brown; scutellum paler. Wing pale, with barely visible veins; 1 poorly marked long radial cell; wing length $0.90-1.30 \mathrm{~mm}$; costal ratio $0.70-0.80$. Legs uniformly pale brown, tarsi slightly paler, coxae dark brown; claws small and equal on all legs; fore femur armed with 4-8 short ventral spines; tarsal ratio of fore leg 1.60-1.90, of mid leg 1.80-2.30, of hind leg 2.10-2.20.

ABDomen. Orange brown.

Genitalia (Fig. 2D-F). Tergite IX short, reaching apex of gonocoxite; sternite IX short. Gonocoxite short, stout; gonostylus long, narrow, distal half curved, with sharp apex. Parameres (Fig. 2E) fused, tongue-like, slightly curved dorsally, with blunt apex. Aedeagus (Fig. 2F) triangular, with low basal arch and barely visible rounded apex.

\section{Female}

HeAD. Brown. Antennal flagellum (Fig. 2C) with short flagellomeres, brown, proximal portions yellow; total flagellum length $0.50-0.70 \mathrm{~mm}$; antennal ratio $0.80-1.10$. Palpus slender, yellow; third palpal segment short, rather stout, without sensory pit; palpal ratio 2.00-2.50. Mandible with 6-8 massive distal teeth and numerous smaller proximal teeth.

THorax. Orange brown; scutellum paler. Wing (Fig. 2A) venation similar to that of male; wing length $1.70-1.80 \mathrm{~mm}$; costal ratio 0.80 . Femoral coloration as in male; fore femur armed with 6-9 ventral spines; fore and mid tibiae with slightly dark bases, occasionally with slightly darker central areas, and dark apices; hind tibia with slightly darker base; tarsal ratio of fore leg 1.80-2.10, of mid leg 1.90-2.50, of hind leg 2.00-2.50.

Aвdomen. Two subspherical seminal capsules (Fig. 2G) with long, thick necks; measuring 0.04-0.05 $\times$ $0.03-0.04 \mathrm{~mm}$ and $0.05-0.06 \times 0.04-0.05 \mathrm{~mm}$.

\section{Distribution}

United Arab Emirates and Yemen. 

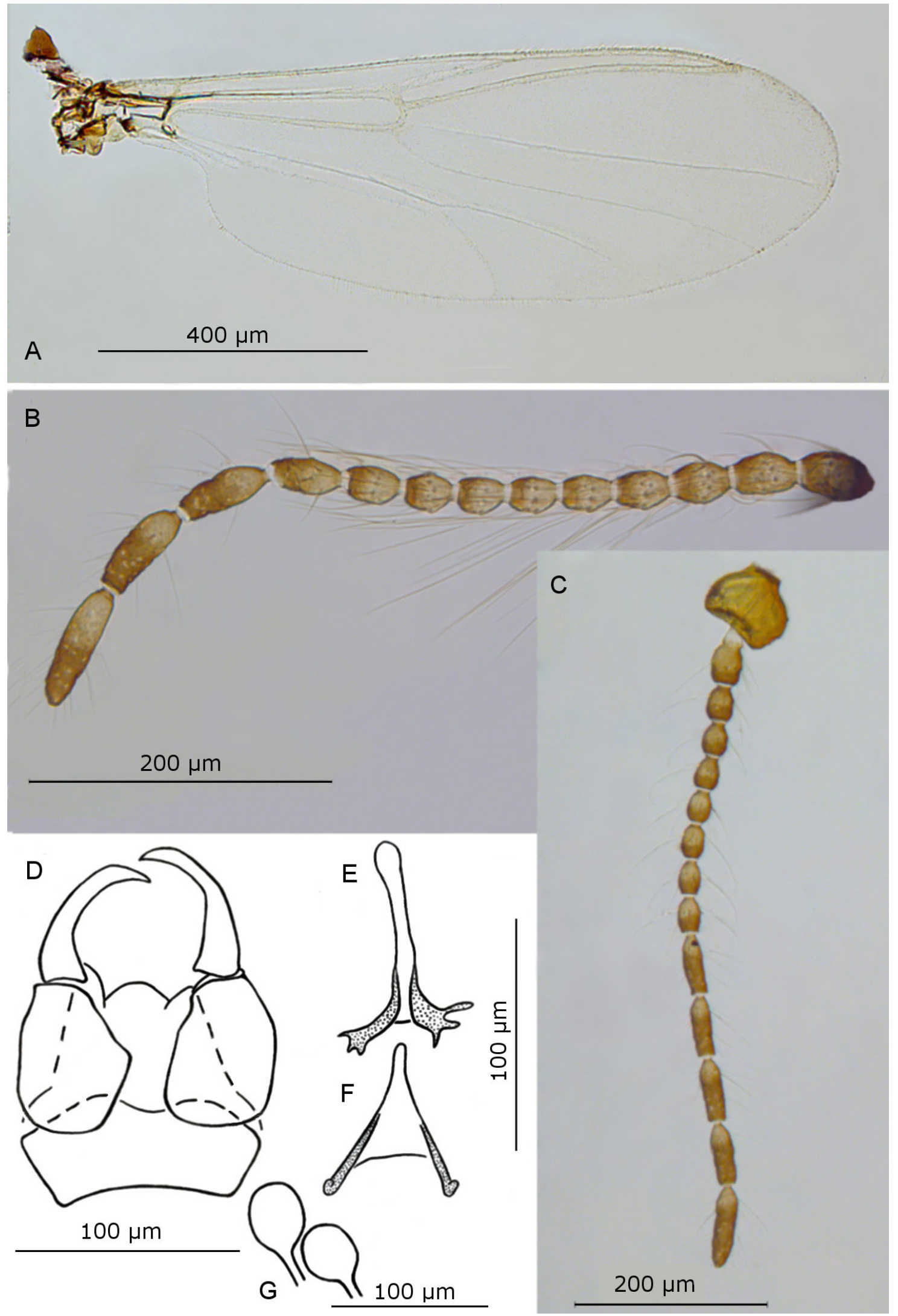

Fig. 2. Bezzia sharjahi Szadziewski \& Alwin sp. nov. A. Wing, ๆ. B. Antennal flagellum, đ̃. C. Antennal

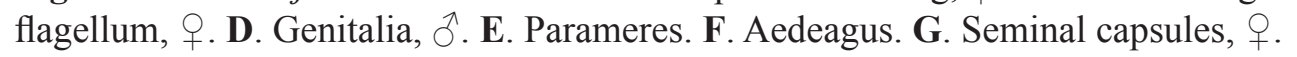




\section{Remarks}

This new species is a typical member of the subgenus Homobezzia. It most closely resembles B. kuhetiensis, which has similar male genitalia and seminal capsules. However, B. kuhetiensis differs from $B$. sharjahi sp. nov. by its whitish legs with distinct, dark bands, the fore femur has only 2 ventral spines, and the parameres are straight.

Subgenus Pygobezzia Remm, 1974

\section{Type species}

Bezzia strobli Kieffer, 1919 (= B. albicornis Meigen, 1818); by original designation.

\section{Diagnosis}

Fore femur with 2-4 ventral spines. Male flagellomere 10 elongate, longer than 11-13; and the flagellar plume is well developed. Aedeagus with slender and very long median process, which is strongly bent dorsally on proximal portion. Gonocoxite slender, elongate; gonostylus reduced, very short, divided into 3-4 tooth-like lobes.

\section{Key to males of Bezzia (Pygobezzia) of the Middle East}

1. Parameres swollen on distal portion, with lateral ribs; scutellum with six large setae

B. albicornis (Meigen, 1818)

- Parameres swollen on proximal portion, without lateral ribs; scutellum with four large setae .....

B. fuliginata Clastrier, 1962

\section{Bezzia (Pygobezzia) albicornis (Meigen, 1818)}

Ceratopogon albicornis Meigen, 1818: 74 ( 0 , Germany).

Ceratopogon calceatus Haliday in Walker, 1856: 239 (Great Britain).

Ceratopogon pallidetarsatus Strobl, 1900: 171 ( + , Spain).

Bezzia strobli Kieffer, 1919: 122 ( $\hat{0}$, o, Hungary).

Bezzia brevinervis Kieffer, 1919: 122 (ð,, , Hungary).

Bezzia trilobata Kieffer, 1922: 237 (ô, o, Germany).

Bezzia aegyptia Kieffer, 1925: 264 (ㅇ, Egypt - Suez). Syn. nov.

Homobezzia atrata Macfie, 1944: 126 (ð,, , figures, description, Egypt).

Bezzia sajana Remm, 1972: 89 (ð, Russia - Siberia).

Bezzia quadridens Remm, 1972: 89 (ð, Russia).

Ceratopogon pallidetarsatus - Becker 1903: 73 (, Egypt).

Bezzia albicornis - Goetghebuer 1922: 58 (combination). — Szadziewski 1984: 184 (= C. pallidetarsatus). - de Meillon \& Wirth 1987: 65 ( $\widehat{\partial}$, ㅇ, South Africa; = C. pallidetarsatus, Bezzia strobli,

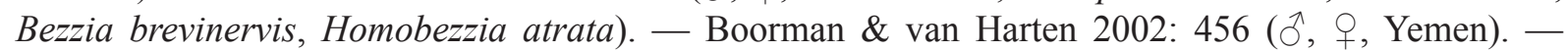
Szadziewski et al. 2011: 649 (ð, , +, United Arab Emirates).

Bezzia atrata - Clastrier 1962: 112 (o,, , descriptions, figures, Algeria).

Bezzia calceata - Tokunaga 1966: 285 (ô,, , Afghanistan).

non Bezzia sajana - Remm 1974: 441 (= B. quadridens).

\section{Diagnosis}

Entirely blackish brown species, except tarsomeres 1-3 pale. Scutellum with 6 large setae. Fore femur with 2-4 ventral spines. Male genitalia large; gonocoxite very long and slender, gonostylus short, divided into 3-4 tooth-like lobes; aedeagus with slender, very long median process that is nearly straight 
ALWIN-KOWNACKA A. et al., Palpomyiini and Sphaeromiini biting midges from the Middle East

on distal portion; parameres fused, expanded on distal portion, with distinct lateral ribs, apex with 2 small processes. Female with 2 ovoid, distinctly unequal seminal capsules.

\section{Material examined}

ISRAEL: 1 q, Sadom, 26 May 1976, A. Freidberg leg. (TAU); 2 qo, Berekhat Ya'ar, 6 Jun. 2003, A. Freidberg leg. (TAU); 1 \%, Besor Nature Reserve, Tel Sharuhen, $31^{\circ} 17^{\prime}$ N, 34 $4^{\circ} 29^{\prime}$ E, 11 May 2005, A. Freidberg leg. (TAU); 1 ' , Herzliya, swamp, $32^{\circ} 10.3^{\prime} \mathrm{N}, 34^{\circ} 49.4^{\prime} \mathrm{E}, 11$ May 2008, A. Freidberg leg. (TAU).

LEBANON: $1 \partial^{\curvearrowright}$, Tyre, $33^{\circ} 16.232^{\prime}$ N, $35^{\circ} 12.706^{\prime}$ E, net, 12 May 2012, P. Dominiak leg. (CEIUG).

\section{Distribution}

Afghanistan, Algeria, Egypt, Europe (Austria, Belgium, Croatia, Czech Republic, France, Germany, Hungary, Lithuania, Poland, Slovakia, Spain, Sweden, Switzerland, Ukraine, former Yugoslavia; Szadziewski et al. 2013), United Arab Emirates, Yemen, South Africa. We provide the first records from Israel and Lebanon.

\section{Remarks}

In the Middle East and North Africa, the subgenus Pygobezzia is represented by two very similar species, B. albicornis and B. fuliginata. The original description of B. aegyptia by Kieffer (1925), based on a single female, is very poor; however, it matches the description of B. albicornis. Unfortunately, the female holotype of B. aegyptia was probably not saved by Kieffer. Accordingly, we regard B. aegyptia as a new junior synonym of $B$. albicornis, because the latter species is more common in the region and was reported earlier from Egypt by Becker (1903) as Ceratoogon pallidetarsata and by Macfie (1944) as B. atrata.

\section{Bezzia (Pygobezzia) fuliginata Clastrier, 1962}

Bezzia fuliginata Clastrier, 1962: 115 (ð̊, Serbia).

Bezzia fulginata - Remm 1967: 32 (Azerbaijan, Georgia); 1973: 351 (Hungary). — Krzywiński 1995: 182 ( ${ }^{\lambda}$, Afghanistan, Azerbaijan, Belgium, Georgia, Poland, Serbia).

\section{Diagnosis}

Very similar to B. albicornis, but differs from that species in having a scutellum with 4 large setae; parameres swollen on proximal portion, without lateral ribs, with 2 distinct apical lobes; apex of median process of aedeagus strongly bent and gonocoxite with 3 ventral bristles.

\section{Material examined}

ISRAEL: 1 ð , Enot Zukim, 7 Dec. 1992, A. Freidberg leg. (TAU); 1 क, Park Rosh ha'Ayin, 16 Apr. 1993, A. Freidberg and F. Kaplan leg. (TAU); 1 O̊, En Mor, 30 Jun. 1994, A. Freidberg leg. (TAU); 1 , Enot Samar, 21 Jun. 1998, A. Freidberg leg. (TAU).

LEBANON: 1 đ, Tyre, $33^{\circ} 15.535^{\prime} \mathrm{N}, 35^{\circ} 12.726^{\prime}$ E, beach, net, 6 May 2012, P. Dominiak leg. (CEIUG).

\section{Distribution}

Afghanistan, Azerbaijan, Europe (France, Hungary, Poland, Serbia, Spain, Ukraine - Crimea), Georgia, Kazakhstan, Turkmenistan, Tajikistan and Uzbekistan (Remm 1988; Krzywiński 1995; Szadziewski et al. 2013). We provide the first records from the Middle East, from Israel and Lebanon. 
Subgenus Sivabezzia Remm, 1974

\section{Type species}

Bezzia campanai Clastrier, 1962; by original designation.

\section{Diagnosis}

Fore femur with 2-4 ventral spines. Male flagellomere 10 elongate, longer than 11-13. Gonocoxite massive; gonostylus well developed, simple; aedeagus composed of small lamella and long median process, which is bent dorsally and directed posteriorly. Female with 2 large seminal capsules, more or less similar in size, both with long necks that are narrowed proximally.

\section{Remarks}

Females of B. melanoflava Clastrier, 1958 and B. pachypyga Remm, 1974 are very similar, with only slight differences in the shapes of their seminal capsules. In $B$. melanoflava they are broadest near the middle portion, whereas in B. pachypyga the widest part is near the proximal portion.

\section{Key to species of Bezzia (Sivabezzia) of the Middle East}

1. Male genitalia with broad parameres (Fig. 3B); submedian process of aedeagus longer than parameres (Fig. 3C); ventral surface of gonocoxite with distinct apical process (Fig. 3A); seminal capsule broadest on proximal portion (Fig. 3D)

B. pachypyga Remm, 1974

- Male genitalia with parameres slender (Fig. 3F); submedian process of aedeagus shorter than parameres (Fig. 3G-H); gonocoxite without subapical process (Fig. 3E); seminal capsule broadest on middle portion (Fig. 3I)

B. melanoflava Clastrier, 1958

Bezzia (Sivabezzia) pachypyga Remm, 1974

Fig. 3A-D

Bezzia pachypyga Remm, 1974: 441 (ฏ, o, figures, Tajikistan, Turkmenistan).

Bezzia omanensis Boorman \& van Harten, 2002: 456 (ð, figures, Oman). Syn. nov.

Bezzia omanensis - Szadziewski et al. 2011: 649 (ð̊, record, United Arab Emirates).

\section{Diagnosis}

\section{Male}

Dark orange-brown species with brownish head; scutum and scutellum same color as rest of thorax. Antenna pale brown, except apical portion of flagellomeres 10 and 11-13, which are darker; flagellomere 10 elongate, longer than 11-13. Palpus pale brown, slender; third segment slender, slightly longer than fourth segment. Legs slender, orange-brown; mid and hind femora darker towards apical portion, without ventral spines; fore femur uniformly brownish, with 3-4 ventral spines; tibiae with a vaguely defined wide, pale central band and narrow, pale basal band; tarsomeres 1-4 yellow, 5 brownish. Male genitalia short (Fig. 3A); sternite IX short, with V-shaped caudomedian excavation; gonocoxite almost $2 \times$ longer than broad, with distinct stout apical process on ventral surface; gonostylus simple, stout, slightly curved, with distinct apical tooth; parameres broad, shield-shaped, distal portion expanded, with massive $\mathrm{W}$-shaped base and concave apex (Fig. 3B); aedeagus short, with low basal arch and armed with slender, dorsal apicomedian process, longer than parameres (Fig. 3C).

\section{Female}

Similar to male with usual sexual differences. Two large seminal capsules, widest in proximal part, both with long necks (Fig. 3D). 


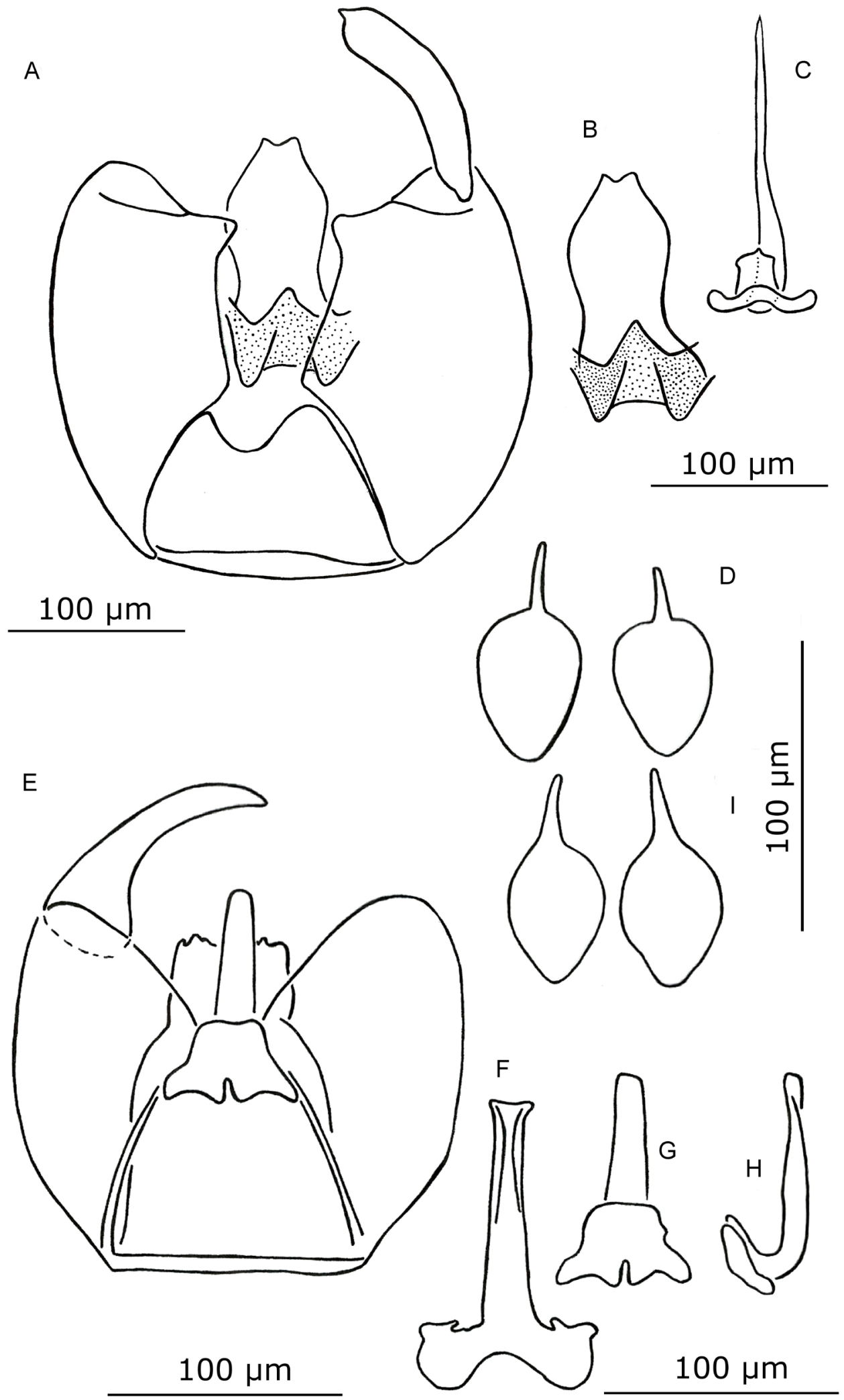

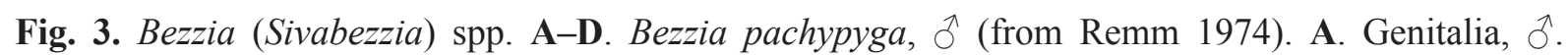
B. Parameres. C. Aedeagus. D. Seminal capsules, ㅇ. - E-I. Bezzia melanoflava (from Clastrier 1958). E. Genitalia, đ. F. Parameres. G. Aedeagus, ventral view. H. Aedeagus, lateral view. I. Seminal capsules, . . 


\section{Material examined}

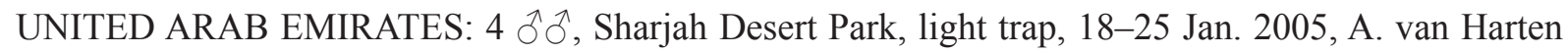
leg. (CEIUG); 4 우, 1 §ิ, same collection data except 16 Jun.-21 Jul. 2005 (CEIUG); 1 o, 1 , , same collection data except 20 Oct. 2005 (CEIUG); 1 ô, same collection data except 10 Dec. 2005 (CEIUG); 1 万, 7 우, same collection data except 1-30 Nov. 2008 (CEIUG); 1 , , same collection data except 27 Nov.-11 Dec. 2008 (CEIUG); 2 đิ 0 , 5 q $q$, same collection data except 11 Dec. 2008-6 Jan. 2009 (CEIUG); 1 ㅇ, same collection data except 12 Jan.-2 Feb. 2009 (CEIUG); 1 o, 1 \&, Fujairah, light trap, 16-24 Feb. 2005, A. van Harten leg. (CEIUG); 1 \&, Hatta, 30 Jan.-26 Feb. 2006, A. van Harten leg. (CEIUG); 1 \&, Al Ajban, 2-9 Apr. 2006, A. van Harten leg. (CEIUG); 1 §ै, Waldi Bih dam, 1-15 Mar. 2007, A. van Harten leg. (CEIUG).

\section{Distribution}

Tajikistan, Turkmenistan. In the Middle East known from Oman and the United Arab Emirates.

\section{Remarks}

The coloration of the legs of Middle East specimens of Bezzia pachypyga is highly variable and different from that in the original description by Remm (1974). However, diagnostic characters of the highly complicated male genitalia match the original descriptions of $B$. pachypyga and its junior synonym B. omanensis Boorman \& van Harten, 2002.

\section{Bezzia (Sivabezzia) melanoflava Clastrier, 1958}

Fig. 3E-I

Bezzia melanoflava Clastrier, 1958: 235 (§ิ, o, figures, description, Senegal).

Bezzia melanoflava - Boorman \& van Harten 2002: 456 (ぷ, o , figure, description, Yemen).

\section{Diagnosis}

This species differs from B. pachypyga in having yellowish legs with indistinct dark brown bands and femora with 2-3 spines. Male gonocoxite simple, without any process (Fig. 3E); parameres slender, rodlike; aedeagus short, with low basal arch, and dorsal, submedian processes shorter than parameres (Figs. 3F-H) (Clastrier 1958; Boorman \& van Harten 2002). Female with 2 conical seminal capsules, widest on middle portion, with long necks (Fig. 3I).

\section{Distribution}

Senegal, Yemen.

Genus Palpomyia Meigen, 1818

\section{Type species}

Ceratopogon flavipes Meigen, 1804; by original designation.

\section{Diagnosis}

Wing with 2 radial cells, costa extending at least $2 / 3$ wing length, but not to apex. Fore femur slender to swollen, usually with stout ventral spines; mid and hind femora slender, often with ventral spines; fifth tarsomeres with or without 2 ventro-lateral rows of stout bristle-like setae; female claws equal, small to enlarged, with or without small, basal inner tooth. Female abdomen with paired internal tergal apodemes and 2 seminal capsules. Male genitalia with prominent cerci; gonocoxite simple or with lobe; aedeagus 
conical or triangular, with well developed basal arms; parameres fused or divided, usually with welldeveloped basal apodemes (de Meillon \& Wirth 1991).

\section{Remarks}

There are no universally recognized subgenera of Palpomyia; however, four species groups have been proposed for this genus: distincta group, flavipes group, lineata group and tibialis group (Grogan \& Wirth 1975, 1979; Spinelli et al. 2009).

\section{Key to males of Middle East Palpomyia}

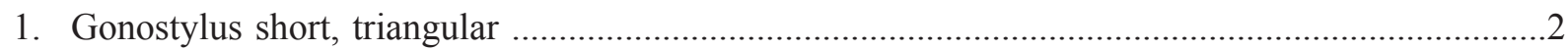

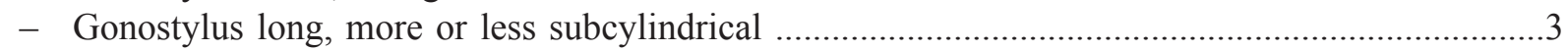

2. Ventral surface of gonostylus covered with numerous coarse ventral setae

.P. tibialis (Meigen, 1818)

- Ventral surface of gonostylus bare ...................................... ebejeri Boorman \& van Harten, 2002

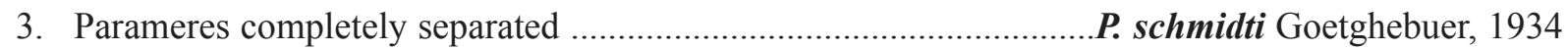

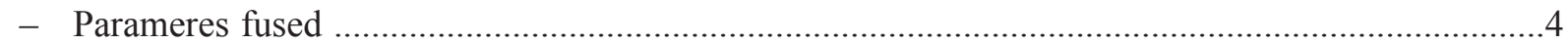

4. Parameres divided into 2 lobes on distal portion ...............................P. serripes (Meigen, 1818)

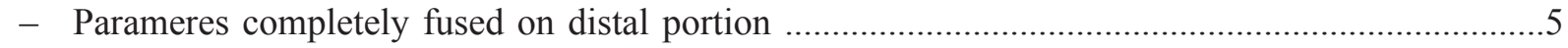

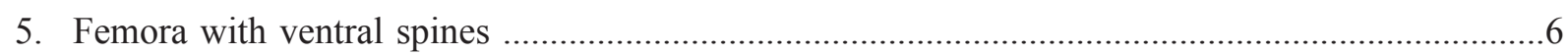

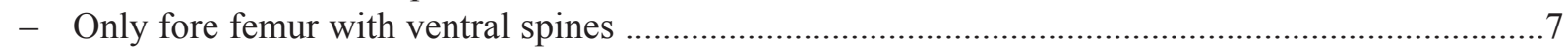

6. Hind tibia with long dorsal bristles; fore and hind femora with 11-12 spines

P. buettikeri Boorman \& van Harten, 2002

- Hind tibia without long dorsal bristles; fore and hind femora with 3 spines

P. mahyoubi Boorman \& van Harten, 2002

7. Hind tibia yellow; fore femur with 3 spines ....................P. nakali Boorman \& van Harten, 2002

- Hind tibia dark brown; fore femur with 4-8 spines ................................................................

8. Body with flattened setae with thin whip-like ends. Femora as well as fore and mid tibiae with dark apices. Male gonocoxite short; gonostylus slender; parameres with blunt expanded apex .....

.P. flavipes (Meigen, 1804)

- Body with simple bristle-like setae. Only hind femur with dark apex. Male gonocoxite elongate; gonostylus swollen on basal portion; parameres with pointed apex

P. freidbergi Alwin \& Szadziewski sp. nov.

\section{Palpomyia distincta group}

Palpomyia buettikeri Boorman \& van Harten, 2002

Palpomyia buettikeri Boorman \& van Harten, 2002: 458 ( $§$, figure, description, Saudi Arabia).

\section{Diagnosis}

Scutum dark brown. Costa reaching more than $3 / 4$ of wing length. Legs uniformly brown; fore femur with 11-12 dark ventral spines; mid femur with 4 longer, more slender spines; hind femur with about 12 very long, slender spines; hind tibia with long dorsal bristles; fifth tarsomeres without ventral setae. 
Male gonocoxite short, stout, with subapical ventral lobe; gonostylus slender, curved, apex pointed; parameres fused, narrowed basally, distal half cylindrical, expanded; aedeagus triangular, with broad apex (Boorman \& van Harten 2002).

\section{Distribution}

Saudi Arabia.

Palpomyia ebejeri Boorman \& van Harten, 2002

Palpomyia ebejeri Boorman \& van Harten, 2002: 458 (ふ̋, figure, description, Oman).

Palpomyia ebejeri - Szadziewski et al. 2011: 651 (ふ̋, o, description, United Arab Emirates).

\section{Diagnosis}

Pale brown species. Legs brown, tarsi paler; fore femur and bases of mid and hind femora pale; male fore femur with 2-3 short spines; mid and hind femora with 1 ventral spine near apex; female fore femur with 8-10, mid femur with 5 , hind femur with 7 spines. Male gonostylus short, triangular, without ventral setae; gonocoxite short, massive, base ventrally expanded; parameres apparently completely separated, apex pointed, strongly bent outwardly; aedeagus with high basal arch and expanded apex. Female with 2 small seminal capsules with short necks.

\section{Material examined}

UNITED ARAB EMIRATES: 1 $\delta$, Wadi Maidaq, light trap, 27 Nov. 2005, A. van Harten leg. (CEIUG); 1 \&, Hatta, light trap, 30 Jan.-26 Feb. 2006, A. van Harten leg. (CEIUG).

\section{Distribution}

Oman, United Arab Emirates.

Palpomyia mahyoubi Boorman \& van Harten, 2002

Palpomyia mahyoubi Boorman \& van Harten, 2002: 458 (ð̊, figure, description, Yemen).

\section{Diagnosis}

Abdomen, scutum, scutellum, femora and tibiae dark brown, without markings. Femora slightly paler toward bases; tarsomeres 1-4 pale, tarsomeres 5 uniformly dark brown; femora with 3 ventral spines. Male gonocoxite slender, elongate, with inner expansion; gonostylus nearly straight (the illustration of the male genitalia in Boorman \& van Harten (2002) is inaccurate); parameres fused, slender, apex not visible in original illustration; aedeagus with very high basal arch, apex plate-like (Boorman \& van Harten 2002). Female unknown.

\section{Distribution}

Yemen.

Palpomyia serripes (Meigen, 1818)

Ceratopogon serripes Meigen, 1818: 82 (ㅇ, Germany).

Ceratopogon flavitarsis Meigen, 1838: 20 (, locality unknown).

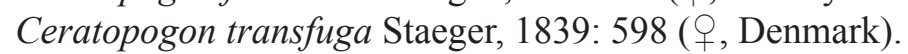

Ceratopogon tarsatus Zetterstedt, 1855: 4874 ( 9 , Sweden).

Palpomyia ruficeps Kieffer, 1918: 59 (†, Tunisia). 
Palpomyia serripes - Kieffer 1906: 63 (combination). — Goetghebuer 1920: 20 (ð, , +, Belgium); 1934:

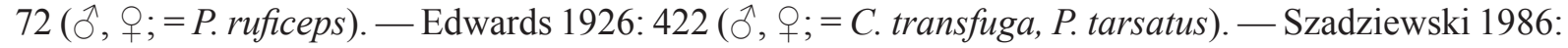
87 ( $\odot$, redescription, distribution, Sweden). — Krzywiński 1995: 55 ( $\curvearrowright$,, , Poland, Sweden). — Turgut \& Kilic 2015: 14 (㝏, Turkey).

\section{Diagnosis}

Body blackish-brown. Palpus and flagellum brown. Legs blackish-brown; fore femur and tarsomeres 1-2 paler, darker distally; tarsomeres 3-5 brown. All femora armed with spines; fore femur with 3-6, mid femur with $0-3$ and hind femur with $0-3$ spines. Female with 2 round seminal capsules with distinct necks. Parameres in male genitalia broad and separated on distal half.

\section{Distribution}

Armenia, Europe (Austria, Belgium, Czech Republic, Croatia, Denmark, Estonia, Finland, France, Germany, Great Britain, Hungary, Ireland, Italy, Lithuania, Netherlands, Norway, Poland, Slovakia, Spain, Sweden, Switzerland), Tunisia, Georgia and Japan. In the Middle East known from Turkey (Szadziewski et al. 2013; Turgut \& Kilic 2015).

\section{Palpomyia flavipes group}

\section{Palpomyia flavipes (Meigen, 1804)}

Ceratopogon flavipes Meigen, 1804: 28 (ð, locality not given).

Ceratopogon hortulanus Meigen, 1818: 81 (ㅇ, Europe).

Ceratopogon flavipes - Walker 1856: 228 ( 9 , Great Britain; = C. hortulanus).

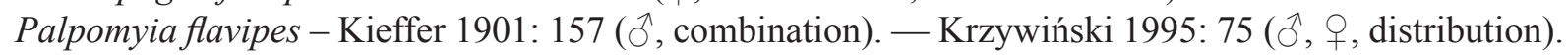

\section{Diagnosis}

Body with flattened setae with thin, whip-like tips; thorax uniformly dark. Legs yellow; femora as well as fore and mid tibiae with apical brown bands; hind tibia brown; fore femur with 5-8 spines. Male genitalia with relatively short gonocoxite; gonostylus almost straight, as long as gonocoxite; parameres fused, slender, expanded apically; aedeagus triangular with low basal arch and evenly rounded apex. Females with 2 large oval seminal capsules with short necks.

\section{Material examined}

ISRAEL: 1 , Dan, 21 Jul. 1983, I. Nussbaum leg. (TAU); 1 q, same collection data except 28 Sep. 1983 (TAU); 1 , , Park Hayarden, 7 May 1987, I. Yarom leg. (TAU); 2 우, same collection data except 7 May 1987, F. Kaplan leg. (TAU); 1 क, same collection data except 14 Apr. 1999, A. Freidberg leg. (TAU); 1 §̂, Lifta, 10 May 1987, I. Nussbaum leg. (TAU).

\section{Distribution}

Armenia, Europe (Andorra, Austria, Belarus, Belgium, Czech Republic, Denmark, Estonia, Finland, France, Germany, Great Britain, Hungary, Ireland, Italy, Latvia, Lithuania, Norway, Poland, N and NW Russia, Slovakia, Ukraine), Georgia, Kazakhstan and Turkey (Remm 1988; Szadziewski et al. 2013; Turgut \& Kilic 2015). The above records are the first from Israel. 
Palpomyia freidbergi Alwin-Kownacka \& Szadziewski sp. nov. urn:1sid:zoobank.org:act:740DBF40-E804-477B-A437-E73110DF1287

Fig. 4

\section{Diagnosis}

This new species is distinguished by the following combination of characters: males with $4-5$ fore femoral ventral spines; very short sternite IX; parameres fused, curved ventrally, apex pointed; and aedeagus with very high basal arch and plate-like apex. Females with 6-9 fore femoral spines; claws without basal inner teeth; and 2 large seminal capsules.

\section{Etymology}

The species is named for Amnon Freidberg, Department of Zoology, Tel Aviv University, Israel, who kindly sent us biting midges from Israel.

\section{Material examined}

\section{Holotype}

ISRAEL: ${ }^{\widehat{O}}$, Enot Zukim, 11 Oct. 1994, A. Freidberg and F. Kaplan leg. (TAU).

\section{Paratypes}

ISRAEL: 4 우, same collection data as holotype except 22 Apr. 1998, A. Freidberg leg. (TAU); 1 , En Feshkha, 11 Aug. 1986, A. Freidberg leg. (TAU); 9 우, Roch Zukim, 10 Apr. 1994, A. Freidberg and F. Kaplan leg. (TAU).

\section{Description}

\section{Male}

HEAD. Uniformly brown. Antenna pale brown, with sparse plume; flagellomeres 9-13 slightly darker than 1-8; flagellomeres 10-13 elongate; total flagellum length of $1.00 \mathrm{~mm}$; antennal ratio 1.40 . Palpus (Fig. 4C) yellowish, slender; third segment cylindrical, with several distinct capitate sensilla; palpal ratio 3.00 .

THORAX (Fig. 4B). Brown with scutum, scutellum, katepisternum and mediotergite slightly darker; scutum, scutellum, anteroanepisternum with fine setae, katepisternum and mediotergite bare; 1 row of 3 bristles posterior to sutura transveralis; 1 bristle on scutum just anterior of scutellum; scutellum with 4 marginal bristles. Wing (Fig. 4A) with distinct veins; first radial cell about $2 \times$ shorter than second; wing length $1.34 \mathrm{~mm}$; costal ratio 0.70 . Legs (Fig. 4B) slender; fore coxa yellow, mid and hind coxae brownish; fore and mid femora yellow, hind femur yellow with dark brown apex; fore femur with 4-5 stout, black ventral spines; fore and mid tibiae yellow, slightly smoky on proximal portions; hind tibia uniformly dark brown; tarsi yellow, tarsomeres 4-5 slightly darker than 1-3; tarsal ratio of fore leg 1.90 , of mid leg 3.30, of hind leg 2.40 .

Abdomen (Fig. 4B). Pale brown.

Genitalia (Fig. 4E-G). Sternite IX (Fig. 4G) narrow. Gonocoxite slender, elongate; gonostylus swollen on basal portion, distal half slender, greatly curved, with blunt apex. Parameres (Fig. 4F) fused, base W-shaped, expanded on mid portion, apex pointed, bent ventrally. Aedeagus (Fig. 4G) triangular; basal arch very high; membrane with numerous fine microtrichia; apex plate-like.

\section{Female}

Similar to male with the usual sexual differences. Antenna uniformly pale brown; total flagellum length of 1.40-1.60 mm; antennal ratio 1.40-1.60. Palpal ratio 4.50. Mandible with 6-7 large teeth. 

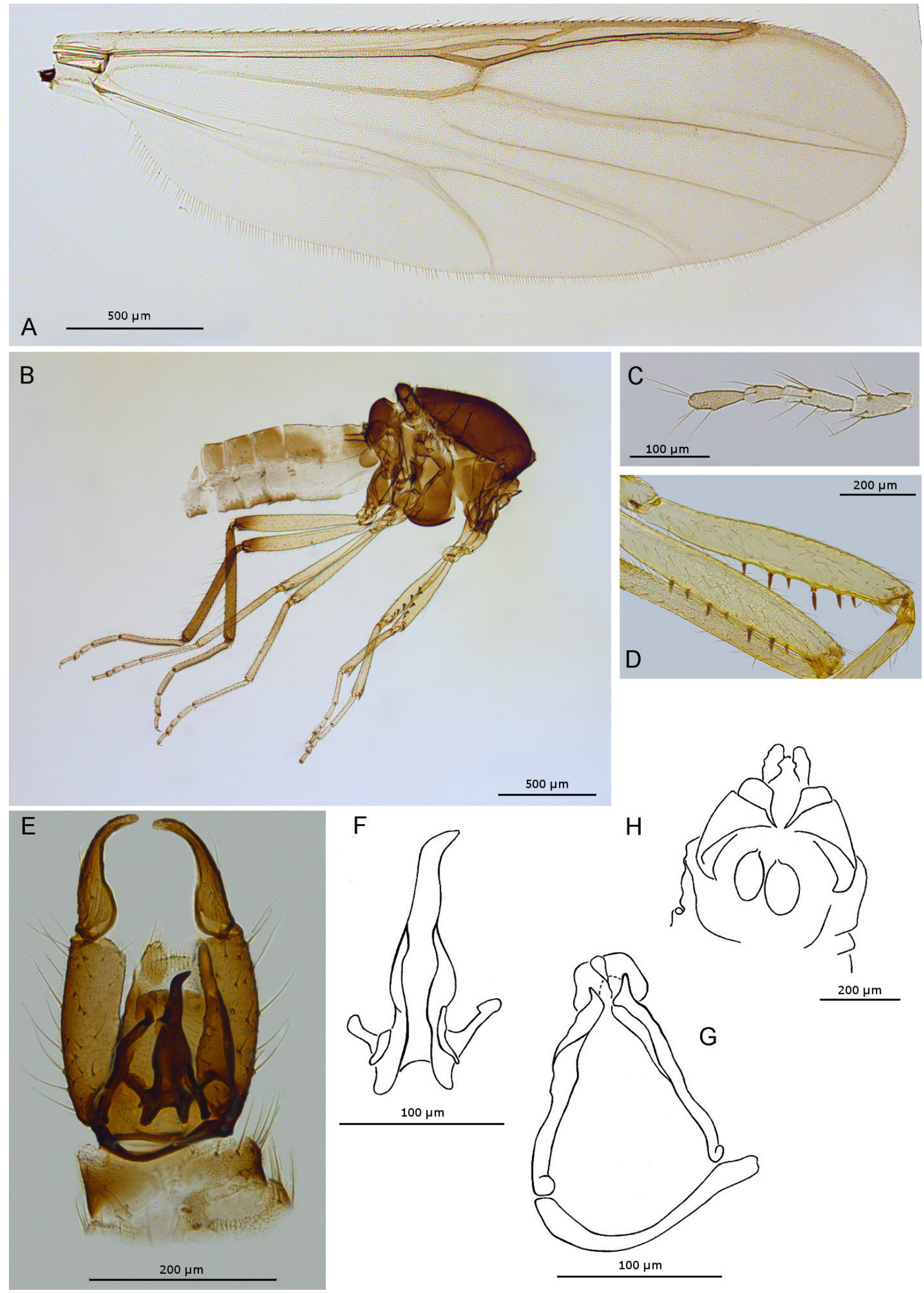

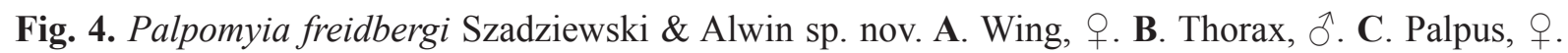
D. Fore femur, + . E. Genitalia, $\widehat{\jmath}$. F. Parameres. G. Aedeagus and sternite IX. H. Seminal capsules. 
THORAX. Coloration and arrangement of bristles as in male. Wing as in male but larger with longer costa (Fig. 4A); wing length 2.10-2.20 mm; costal ratio 0.80. Coloration of legs as in male; fore femur armed with 6-9 stout, black ventral spines (Fig. 4D); tarsal ratio of fore leg 2.10-2.40, of mid leg 3.80-4.50, of hind leg 2.30-2.50.

ABdomen. Pale brown, with 2 pairs of internal tergal apodemes. Two large, subequal, ovoid seminal capsules (Fig. $4 \mathrm{H}$ ) with short necks, measuring $0.08-0.10 \times 0.12-0.14 \mathrm{~mm}$ and $0.06-0.08 \times 0.10-0.12$ $\mathrm{mm}$.

\section{Distribution}

Israel; known only from the type locality.

\section{Remarks}

Males of this new species have an aedeagus with an unusual plate-like apex that is similar to that of males of $P$. mahyoubi from Yemen. This newly described species differs mostly in having pale legs with a dark brown hind tibia, only the fore femur armed with ventral spines and a distinctly curved gonostylus. Males of $P$. mahyoubi have a nearly straight gonostylus, dark brown legs, and all femora have ventral spines.

Palpomyia nakali Boorman \& van Harten, 2002

Palpomyia nakali Boorman \& van Harten, 2002: 459 (ð̂, figure, description, Oman).

\section{Diagnosis}

Scutum and abdomen pale orange-brown. Legs pale, non-banded, without obvious darker bands; fore femur with 3 spines. Male genitalia with gonocoxite and gonostylus long, slender; parameres fused, with slender apical portion; aedeagus broadly triangular, probably with apical cap (Boorman \& van Harten 2002).

\section{Distribution}

Oman.

Palpomyia schmidti Goetghebuer, 1934

Palpomyia schmidti Goetghebuer, 1934: 36 (†, Iraq, Iran).

Palpomyia miki Goetghebuer, 1934: 91 (․, Hungary).

Palpomyia miki-Remm 1976: 175 (ㅇ, ô, Russia).

Palpomyia schmidti - Szadziewski et al. 2009: 195 (ㅇ, §̂, Iraq).

\section{Diagnosis}

Body pale brown. Legs yellowish; fore femur with 5-8 spines, mid and hind femora with 1-3 spines; mid and hind tibiae with numerous large setae; tarsomere 1 of mid leg with medial spines. Male gonocoxite with long ventral apodeme; gonostylus evenly bent, with pointed apex; parameres separate with swollen apices; aedeagus broadly triangular. Female with simple claws; with 2 ovoid seminal capsules with short necks (Szadziewski et al. 2009).

\section{Material examined}

TURKEY: 1 , Aydiklar, 21 Jul. 2004, R. Dobosz leg. (CEIUG). 
ALWIN-KOWNACKA A. et al., Palpomyiini and Sphaeromiini biting midges from the Middle East

\section{Distribution}

Azerbaijan, Europe (Hungary, Spain, Slovakia, Ukraine), Iran, Iraq, Kazakhstan, Mongolia, Russia (S Siberia), Tajikistan, Turkey (Szadziewski et al. 2009).

\section{Palpomyia tibialis group}

Palpomyia tibialis (Meigen, 1818)

Ceratopogon tibialis Meigen, 1818: 82 (q, Europe).

Palpomyia atripectus Kieffer, 1919: 101 ( + , Hungary, Serbia).

Palpomyia laticollis Goetghebuer, 1922: 55 (ふ̋, Belgium).

Palpomyia nipponica Tokunaga, 1939: 297 (ठ, ㅇ, Japan).

Palpomyia tibialis - Kieffer 1901: 156 (combination, in key).

\section{Diagnosis}

Dark brown species. Fore and mid legs pale brown to yellow; coxae brown; hind femur dark brown on distal $1 / 4(+)$ or $1 / 2\left(\delta^{\lambda}\right)$, hind tibia dark. Fore femur with $6-9$, mid femur with $0-2$ and hind femur with 1-3 ventral spines; fifth tarsomere of hind leg with 2 rows of large setae. Male gonocoxite long, basally expanded, with small ventral bulge on distal portion covered with small setae; gonostylus triangular, with short, stout setae on ventral surface; parameres fused only on extreme basal portion, apices elongate, slender, pointed, recurved. Female with 2 ovoid seminal capsules with distinct necks.

\section{Distribution}

North America (Grogan \& Wirth 1979; Borkent \& Grogan 2009), Azerbaijan, N China, Europe (Austria, Belarus, Belgium, Czech Republic, Denmark, Estonia, Finland, France, Germany, Hungary, Netherlands, Norway, Poland, Romania, N and NW Russia, Serbia, Slovakia, Sweden, Ukraine and former Yugoslavia), Georgia, Japan and Tajikistan. From the Middle East known from Turkey (Remm 1988; Szadziewski et al. 2013; Turgut \& Kilic 2015).

Genus Phaenobezzia Haeselbarth, 1965

\section{Type species}

Probezzia pistiae Ingram \& Macfie, 1921; by original designation.

\section{Diagnosis}

Large, slender, nearly bare midges. Legs slender; femora unarmed; female fifth tarsomeres with long, stout, sharp setae with bent tips. Female claws equal, evenly curved or bent at base, each with small basal inner tooth. Wing with 1 radial cell; costa extending $0.80-0.90$ of wing length. Gonostylus very small, rarely absent (de Meillon \& Wirth 1991).

Phaenobezzia spekei (Macfie, 1939)

Nilobezzia spekei Macfie, 1939: 101 (ㅇ, description, Uganda).

Phaenobezzia spekei - Boorman \& van Harten 2002: 459 ( $q$ and ${ }^{\lambda}$ recorded, diagnosis of $q$, Yemen).

\section{Diagnosis}

Scutum dark brown, scutellum paler, with 8 bristles. Fore leg yellow; tibia darker towards tip; tarsomeres 3-5 dark; mid leg similarly colored but tarsus darker; hind leg with yellow femur, dark tibia and tarsus with bristles. Female fifth tarsomeres with 3-4 pairs of sharp, black, spine-like setae with bent tips; 2 
large seminal capsules with long necks (Boorman \& van Harten 2002). Boorman \& van Harten (2002) reported males from Yemen, but they were not diagnosed or illustrated.

\section{Distribution}

Uganda, Yemen.

Tribe Sphaeromiini Newman, 1834

\section{Key to genera of Middle East Sphaeromiini}

1. Tibiae with stout bristles 2

- Tibiae without stout bristles 3

2. Parameres fused, H-shaped; female claws with short basal external tooth

Nilobezzia Kieffer, 1921

- Parameres fused, Y-shaped; female claws with short basal inner tooth

Sphaeromias Curtis, 1829

3. Wing with one radial cell

Macropeza Meigen, 1818

- Wing with two radial cells

4. Parameres separate; female claws equal on fore leg, unequal on mid and hind legs

Johannsenomyia Malloch, 1915

- Parameres fused; female claws equal on all legs Homohelea Kieffer, 1917

Genus Homohelea Kieffer, 1917

\section{Type species}

Palpomyia abjuncta Kieffer, 1913; by original designation.

\section{Diagnosis}

Large, grayish, stout-bodied midges. Legs stout; femora with 4-8 stout, black ventral spines; fifth tarsomeres of female with 2 pairs of batonnets; female claws long, equal, curved, on fore leg with basal inner teeth. Wings with 2 radial cells and long costa that extends to near wing tip. Male genitalia short, stout; gonostylus stout, with slender hooked tip; aedeagus with high basal arch and stout tip; parameres fused except basally (de Meillon \& Wirth 1991). Female abdomen without ventral setal tufts on sternite VIII; 2 seminal capsules.

Homohelea telmatoscopa (Ingram \& Macfie, 1921)

Schizodactylus telmatoscopus Ingram \& Macfie, 1921: 353 (ô, ㅇ, description, figures, Ghana).

Homohelea telmatoscopa - de Meillon \& Wirth 1981: 542 (key to sub-Saharan species of Homohelea); Boorman \& van Harten 2002: 455 ( , Yemen).

\section{Diagnosis}

Thorax uniformly dark brown; small prothoracic lobes present. Flagellum dark brown. Palpus very small; third segment not swollen, sensory pit rudimentary. Femora with 10-12 ventral spines; femora and tibiae dark brown, tarsomeres 1-4 paler; tarsomeres 5 dark brown, with 2 pairs of dark batonnets; female claws long and equal, fore claws with a large basal inner tooth. Female with 2 ovoid seminal capsules with short necks (Ingram \& Macfie 1921). 
ALWIN-KOWNACKA A. et al., Palpomyiini and Sphaeromiini biting midges from the Middle East

\section{Distribution}

Ghana, Yemen.

Genus Johannsenomyia Malloch, 1915

\section{Type species}

Johannsenomyia halteralis Malloch, 1915; by original designation.

\section{Diagnosis}

Slender midges. Legs long, slender, apices of femora clubbed, especially on fore femur; femora usually without ventral spines; tarsomeres 5 of females with numerous pairs of batonnets, males with 2-3 pairs of batonnets; female claws unequal on mid and hind legs, longer claw slightly curved, each claw with short, stout basal inner tooth. Wings with 2 radial cells (rarely 1); costa moderately long (female costal ratio about 0.80 ). Male tergite IX rounded distally; aedeagus broad, with cap-like tip; parameres separate, basal portion curved, apical portion broad, flattened (de Meillon \& Wirth 1991). Female abdomen petiolate, narrow at base, sternite VIII without setal tufts; 2 large seminal capsules.

\section{Johannsenomyia imparunguis (Becker, 1903)}

Ceratopogon imparunguis Becker, 1903: 72 (, description, Egypt).

Ceratolophus imparunguis - Kieffer 1906: 60 (combination).

Palpomyia imparunguis - Kieffer 1917: 364 (combination).

Allohelea imparunguis - Kieffer 1925: 263 (combination).

Johannsenomyia imparunguis - Szadziewski 1984: 189 (combination, ㅇ, redescription).

\section{Diagnosis}

Scutellum and scutum blackish-brown. Wings pale; second radial cell 4 times as long as first. Halteres with proximal half yellow, distal half blackish-brown. Legs slender, unarmed; female with 2 equal fore claws, claws with 1 large inner basal tooth, mid and hind legs with single long claw and 3 basal teeth as in fore claws; fore and hind tarsomeres 5 with 5 pairs of batonnets. Females with 2 large, oval seminal capsules with short necks and a distinct seminal duct (Szadziewski 1984).

\section{Distribution}

Egypt.

Genus Macropeza Meigen, 1818

\section{Type species}

Macropeza albitarsis Meigen, 1818; by original designation.

\section{Diagnosis}

Large midges. Wings narrow, with 1 radial cell; female costa extends to wing tip, male radial cell shorter. Legs slender; femora unarmed; tarsomeres 5 of female with several pairs of batonnets; female claws short, curved, equal on all legs, with a short basal outer tooth. Male genitalia elongate, slender; gonocoxite elongate, gonostylus short; aedeagus short to elongate with rounded to truncate apex; parameres separate, each with heavily sclerotized, ventrally recurved, hook-like process (de Meillon \& Wirth 1991). Female abdomen with pair of lateral setal tufts on sternite VIII; 2 large seminal capsules. 
Macropeza nuda (Becker, 1903)

Macroptilum nudum Becker, 1903: 77 (ð̊, o, description, Egypt).

Macropeza nuda - Wirth \& Ratanaworabhan 1972: 216 (combination). — Szadziewski 1986: 85 (ㅇ, redescription, Egypt).

\section{Diagnosis}

Blackish-brown midges. Scutellum with 2 lateral, 2 submedian setae. Wing with brownish radial cell. Legs brown, except tarsomeres 1-2 of fore and mid legs and tarsomeres 1-4 of hind leg paler; hind tibial comb with 7 spines; tarsomeres 1 of all legs with 2 pairs of spines; female claws stout, nearly equal, with short basal outer teeth, male claws simple. Female with 2 elongate seminal capsules with very short necks (Szadziewski 1986).

\section{Distribution}

Egypt.

Genus Nilobezzia Kieffer, 1921

\section{Type species}

Nilobezzia armata Kieffer, 1921; by original designation.

\section{Diagnosis}

Large robust midges. Wing often whitish at base, with distal or marginal infuscation; 1 or 2 radial cells; costa moderately short (female costal ratio about 0.80 ). Legs slender; femora slender to moderately swollen distally, females with short ventral spines, males with long, slender setae; hind tibia with long spine-like setae; female tarsomeres 5 with numerous ventral batonnets; female claws large, equal and bent at base, nearly straight distally, with short basal outer teeth. Male genitalia rotated and bent ventrally so that sternal surface is oriented caudally; gonocoxite and gonostylus poorly developed, usually fused, gonostylus short, thumb-like, immovable; aedeagus with short basal arch and cap-like tip; parameres with bulbous fused basal portion, distal halves elongate, tightly adpressed, tips slightly bulbous (de Meillon \& Wirth 1991). Female abdomen with 2 small, slender sclerites and pair of setal tufts on sternite VIII; 2 seminal capsules.

\section{Remarks}

We are unable to distinguish Nilobezzia nilotica from N. nigritibialis and were not able to borrow the holotypes of either species or have access to them. Moreover, the original description of N. nilotica, by Kieffer (1925), is very poor and not helpful in distinguishing either species.

Nilobezzia nilotica (Kieffer, 1925)

Parrotia nilotica Kieffer, 1925: 263 (つ, Egypt).

\section{Diagnosis}

Black species. Legs brown, tarsi whitish, distal tarsomeres black, femora unarmed.

\section{Distribution}

Egypt. 
ALWIN-KOWNACKA A. et al., Palpomyiini and Sphaeromiini biting midges from the Middle East

\section{Remarks}

The genus Parrotia Kieffer, 1923 was placed as subgenus within Nilobezzia by Lane (1958: 25).

Nilobezzia nigritibialis (Ingram \& Macfie, 1921)

Dicrobezzia nigritibialis Ingram \& Macfie, 1921: 371 (§,,+ , descriptions, figures, Ghana).

Nilobezzia nigritibialis - Clastrier \& Wirth 1961: 212 (combination). — Boorman \& Harten 2002: 455 (†, description, Oman, Yemen).

\section{Diagnosis}

Very dark brown midges. Legs with femora and tibiae dark brown; tarsomeres 1-4 pale brown, tarsomeres 5 dark brown; female claws large, equal, with basal outer teeth; female tarsomeres 5 armed with 8-10 black slender batonnets. Male with moderately well developed gonocoxite, broad basally, gonostylus conical and reduced; aedeagus with high basal arch and broad, cap-like apex (Boorman \& Harten 2002). Female with 2 subspherical, unequal seminal capsules.

\section{Distribution}

Ghana, Oman, Yemen (Boorman \& Harten 2002).

Genus Sphaeromias Curtis, 1829

\section{Type species}

Sphaeromias albomarginatus Curtis, 1829; by original designation.

\section{Diagnosis}

Large, grayish pollinose midges. Legs slender; femora with numerous spines; hind tibia with long dorsal spine-like setae; female tarsomeres 5 with numerous slender batonnets; female claws large, curved, equal, with long, slender, sharp basal inner teeth. Wings with 2 radial cells; female costa long, extending nearly to wing tip. Male gonocoxite and gonostylus elongate; aedeagus with broad, cap-like apex; parameres fused, Y-shaped, distal portion becoming increasingly broader distally, apex rounded, setose (de Meillon \& Wirth 1991). Female abdomen without pair of sclerites or setal tufts on sternite VIII; 2 seminal capsules.

\section{Sphaeromias pictus (Meigen, 1818)}

Ceratopogon pictus Meigen, 1818: 80 (ㅇ, Germany).

Ceratopogon punctatus Meigen, 1830: 264 ( 9 , probably Germany).

Ceratopogon elegans Winnertz, 1852: 58 ( 9 , Poland).

Xylocrypta miricornis Kieffer, 1919: 77 (ò, Hungary).

Sphaeromias pictus - Goetghebuer 1934: 59 (combination; = C. elegans).

\section{Diagnosis}

Body brown, scutellum slightly paler. Legs brown, mid and hind legs darkest; fore tibia with distinct pale band at apex (poorly developed on mid tibia); tarsomeres 1-4 yellow, with more or less brown tips, tarsomeres 5 brown; fore femur slightly swollen, with 8-9 ventral spines, mid femur slender, with 5-6 spines, hind femur with 8-10 spines; tarsomeres 5 with 6 massive ventral batonnets; female claws equal, long, curved, with basal inner teeth. Female with 2 sub-equal, rounded seminal capsules with short necks, and distinct seminal duct. 
Table 1. Zoogeographical elements among the Middle East Palpomyiini and Sphaeromiini.

\begin{tabular}{|c|c|}
\hline \multicolumn{2}{|l|}{ Afrotropical } \\
\hline Bezzia melanoflava & Senegal; Yemen \\
\hline Phaenobezzia spekei & Uganda; Yemen \\
\hline Homohelea telmatoscopa & Ghana; Yemen \\
\hline Nilobezzia nigritibialis & Ghana; Oman, Yemen \\
\hline \multicolumn{2}{|l|}{ Saharo-Arabian } \\
\hline Bezzia libanensis sp. nov. & Lebanon \\
\hline Bezzia mellori & Oman \\
\hline Bezzia naseri & Yemen \\
\hline Bezzia sharjahi sp. nov. & United Arab Emirates, Yemen \\
\hline Palpomyia buettikeri & Saudi Arabia \\
\hline Palpomyia ebejeri & Oman, United Arab Emirates \\
\hline Palpomyia mahyoubi & Yemen \\
\hline Palpomyia nakali & Oman \\
\hline Palpomyia freidbergi sp. nov. & Israel \\
\hline Johannsenomyia imparunguis & Egypt \\
\hline Macropeza nuda & Egypt \\
\hline Nilobezzia nilotica & Egypt \\
\hline \multicolumn{2}{|l|}{ Palearctic } \\
\hline Bezzia albicornis & $\begin{array}{l}\text { Algeria, Afghanistan, Europe, South Africa; Egypt, Israel, Lebanon, United Arab } \\
\text { Emirates, Yemen }\end{array}$ \\
\hline Bezzia fuliginata & $\begin{array}{l}\text { Afghanistan, Azerbaijan, Europe, Georgia, Kazakhstan, Turkmenistan, Tajikistan, } \\
\text { Uzbekistan; Israel, Lebanon }\end{array}$ \\
\hline Bezzia flavicornis & Azerbaijan, Central Russia, Europe, Kyrgyzstan; Israel \\
\hline Bezzia kuhetiensis & Azerbaijan, Ukraine; Turkey \\
\hline Bezzia pachypyga & Tajikistan, Turkmenistan; Oman, United Arab Emirates \\
\hline Palpomyia schmidti & Azerbaijan, Europe, Kazakhstan, Mongolia, S Russia, Tajikistan; Iran, Iraq, Turkey \\
\hline Palpomyia flavipes & Armenia, Georgia, Kazakhstan, Europe; Turkey, Israel \\
\hline Palpomyia serripes & Armenia, Georgia, Europe, Tunisia; Turkey \\
\hline Sphaeromias pictus & China, Europe, Japan, Kazakhstan, Kyrgyzstan, Russia; Israel \\
\hline \multicolumn{2}{|l|}{ Holarctic (Palearctic + Nearctic) } \\
\hline Palpomyia tibialis & $\begin{array}{l}\text { North America, Azerbaijan, N China, Europe, Georgia, Japan, N and NW Russia, } \\
\text { Tajikistan; Turkey }\end{array}$ \\
\hline
\end{tabular}

\section{Material examined}

ISRAEL: 1 , Golan Aniam, 18 May 1983, A. Freidberg leg. (TAU); 2 q , Hula, 1 Jul. 1993, A. Freidberg leg. (TAU); 1 , , Berekhat Ya'ar, 14 May 2003, A. Freidberg leg. (TAU); 2 우, same collection data except 23 May 2003 (TAU); 1 , , En HaHoresh, 21 May 2005, A. Freidberg leg. (TAU).

\section{Distribution}

Belarus, Belgium, Great Britain, China, Czech Republic, Estonia, Finland, France, Germany, Hungary, Italy, Japan, Kazakhstan, Kyrgyzstan, Latvia, Lithuania, Poland, Russia (central, northwest and southern regions), Slovakia, Ukraine (Remm 1988; Szadziewski et al. 2013). We provide the first records for the Middle East, from Israel. 


\section{Discussion}

In the Middle East the tribe Palpomyiini is represented by 20 species in three genera. Nine are known only from the Middle East or the Saharo-Arabian Region (Table 1). Nine species occur in the Palearctic Region, including several species also reported from the Nearctic Region, whereas only two species have been recorded from the Afrotropical Region. The tribe Sphaeromiini is represented by only six species in five genera in the Middle East. Three species are recorded from the Saharo-Arabian Region, two from the Afrotropics, and one from the Palearctic.

\section{Acknowledgements}

We are grateful to Dr. Amnon Freidberg (TAU) who kindly sent us materials from Israel. Special thanks are directed to Dr Antonius van Harten for collecting and making available to us specimens from the United Arab Emirates and Yemen, and to Professor Dany Azar (Lebanese University) for his help during field research. This is a contribution to the cooperative agreement between the Lebanese University and University of Gdańsk in the project "Origin and Evolution of Terrestrial Biodiversity of Europe and the Middle East".

We are also grateful to Dr. William L. Grogan Jr and an anonymous referee for reviewing the manuscript and providing valuable comments.

\section{References}

Alwin-Kownacka A., Szadziewski R. \& Szwedo J. 2016. Biting midges of the tribe Ceratopogonini (Diptera: Ceratopogonidae) from the Middle East, with keys and descriptions of new species. Zootaxa 4079 (5): 551-572. https://doi.org/10.11646/zootaxa.4079.5.3

Becker T. 1903. Ägyptische Dipteren. Mitteilungen aus dem zoologischen Museum in Berlin 2: 67-195.

Boorman J. \& van Harten A. 2002. Some Ceratopogonidae (Insecta: Diptera) from the Arabian Peninsula, with particular reference to the Republic of Yemen. Fauna of Arabia 19: 427-462.

Borkent A. 2016. World species of biting midges (Diptera: Ceratopogonidae). Available from http:// www.inhs.illinois.edu/research/FLYTREE/CeratopogonidaeCatalog.pdf [accessed 6 Jul. 2016].

Borkent A. \& Grogan Jr W.L. 2009. Catalog of the New World biting midges north of Mexico (Diptera: Ceratopogonidae). Zootaxa 2273: 1-48.

Clastrier J. 1958. Notes sur les Cératopogonidés. IV. Cératopogonidés d'Afrique Occidentale française. Archives de l'Institut Pasteur d'Algérie 36: 192-258.

Clastrier J. 1962. Notes on Ceratopogonidae. XVI. Species of the genus Bezzia Kieffer or related species of the Palearctic Region. Archives de l'Institut Pasteur d'Algérie 40: 53-125.

Clastrier J. \& Wirth W.W. 1961. Notes on Ceratopogonidae. XIII. Ceratopogonidae of the Ethiopian region. Archives de l'Institut Pasteur d'Algerie 39: 190-240.

Edwards, F.W. 1926. On the British biting midges (Diptera, Ceratopogonidae). Transactions of the Royal Entomological Society of London 74: 389-426. https://doi.org/10.1111/j.1365-2311.1926.tb02249.x

Goetghebuer M. 1920. Ceratopogoninae de Belgique. Mémoires du Musée royal d'Histoire naturelle de Belgique 8 (3): 1-116. Available from http://biodiversitylibrary.org/page/42372753 [accessed 4 Apr. 2017].

Goetghebuer M. 1922. Étude critique des Ceratopogon de la collection Meigen conservée au Muséum national d'Histoire naturelle de Paris. Bulletin de la Société entomologique de Belgique 4: 50-59. 
Goetghebuer M. 1934. A. Die Imagines. Heleidae (Ceratopogonidae). 13a. In: Lindner E. (ed.) Die Fliegen der Palaearktischen Region: 1-94. E. Schweizerbart'sche Verlagsbuchhandlung, Stuttgart.

Grogan Jr W.L. \& Wirth W.W. 1975. A revision of the genus Palpomyia Meigen of northeastern North America (Diptera: Ceratopogonidae). University of Maryland Agricultural Experiment Station Miscellaneous Publication 875: 1-49.

Grogan Jr W.L. \& Wirth W.W. 1979. The North American predaceous midges of the genus Palpomyia Meigen (Diptera: Ceratopogonidae). Memoirs of the Entomological Society of Washington 8: 1-125.

Ingram A. \& Macfie J.W.S. 1921. West African Ceratopogonidae. Annals of Tropical Medicine and Parasitology 15: 313-377.

Kieffer J.J. 1901. Synopse des representants européens du groupe Ceratopogon, avec description d'espèces nouvelles. Bulletin de la Société d'Histoire naturelle de Metz 9: 143-165. Available from http://biodiversitylibrary.org/page/33770412 [accessed 3 Apr. 2017].

Kieffer J.J. 1906. Chironomidae. In: Wytsman P. (ed.) Genera Insectorum 42: 1-78. Verteneuil \& Desmet, Brussels.

Kieffer J.J. 1917. Chironomides d'Australie conservés au Musée national hongrois de Budapest. Annales Musei Nationalis Hungarici 15: 175-228.

Kieffer J.J. 1918. Chironomides d'Afrique et d'Asie conservés au Museum national hongrois de Budapest. Annales Musei Nationalis Hungarici 16: 31-139.

Kieffer J.J. 1919. Chironomides d'Europe conservés au Musée national hongrois de Budapest. Annales Musei Nationalis Hungarici 17: 1-160.

Kieffer J.J. 1922. Nouveaux chironomides piqueurs habitant le Sleswig-Holstein. Annales de la Société scientifique de Bruxelles 41: 230-238. Available from http://biodiversitylibrary.org/page/44916070 [accessed 4 Apr. 2017].

Kieffer J.J. 1925. Chironomides d'Egypte (Dipt.). Bulletin de la Société royale entomologique d'Egypte 8: 244-313.

Krzywiński J. 1995. Rewizja Systematyczna Drapieżnych Kuczmanów Plemienia Palpomyiini Polski (Diptera: Ceratopogonidae). PhD Thesis (manuscript). Uniwersytet Gdański, Gdańsk, Poland.

Lane J. 1958. On Neotropical Bezzia. Revista Brasileira de Entomologia 8: 25-36.

Macfie J.W.S. 1939. Ceratopogonidae. In: Ruwenzori Expedition 1934-35 1: 81-102. British Museum of Natural History.

Macfie J.W.S. 1944. A new species of Homobezzia (Diptera, Ceratopogonidae) from Egypt. Proceedings of the Royal Entomological Society of London B 13: 125-126. https://doi.org/10.1111/j.1365-3113.1944. $\underline{\mathrm{tb} 00770 . \mathrm{x}}$

Meigen J.W. 1804. Klassifikation und Beschreibung der Europäischen Zweiflügeligen Insekten (Diptera Linn.). Vol. 1. XXX, Braunschweig.

Meigen J.W. 1818. Systematische Beschreibung der bekannten Europäischen Zweiflügeligen Insekten. Part 1. Beaufort Sohn, Aachen, Germany. Available from http://biodiversitylibrary.org/page/12741784 [accessed 4 Apr. 2017].

Meigen J.W. 1830. Systematische Beschreibung der bekannten Europäischen Zweiflügeligen Insekten. Part 6. Schulzische Buchhandlung, Hamm, Germany. Available from http://biodiversitylibrary.org/ page/12754233 [accessed 4 Apr. 2017]. 
Meigen J.W. 1838. Systematische Beschreibung der bekannten Europäischen Zweiflügeligen Insekten. Part 7 or Supplement. Schulzische Buchhandlung, Hamm, Germany. Available from http:// biodiversitylibrary.org/page/12841287 [accessed 4 Apr. 2017].

Meillon B. de \& Wirth W.W. 1981. Subsaharan Ceratopogonidae (Diptera). VI. New species and records of South African biting midges collected by A.L. Dyce. Annals of the Natal Museum 24: 525-561.

Meillon B. de \& Wirth W.W. 1987. Subsaharan Ceratopogonidae (Diptera). XII. New species and records, mainly from South Africa. Journal of the Entomological Society of Southern Africa 50: 35-74.

Meillon B. de \& Wirth W.W. 1991. The genera and subgenera (excluding Culicoides) of the Afrotropical biting midges (Diptera: Ceratopogonidae). Annals of the Natal Museum 32: 27-147.

Remm H. 1967. On the fauna of Ceratopogonidae (Diptera) in the Caucasus. Tartu Riikliku Ülikooli Toimetised 194: 3-37.

Remm H. 1972. Novye vidy mokrecov iz Južnoj Sibiri. Tartu Riikliku Ülikooli Toimetised 293: 62-90.

Remm H. 1973. Beiträge zur Ceratopogoniden-Fauna Ungarns (Diptera). Folia Entomologica Hungarica 26: 349-357.

Remm H. 1974. A review of species of the genus Bezzia Kieffer (Diptera, Ceratopogonidae) from the fauna of the USSR. Entomologicheskoe Obozrenie 53: 429-442.

Remm H. 1976. A synopsis of the Palpomyia of the USSR (Diptera, Ceratopogonidae). Proceedings of the Estonian Academy of Sciences 65: 172-197.

Remm H. 1988. Family Ceratopogonidae. In: Soos Á. \& Papp L. (eds) Catalogue of Palaearctic Diptera 3: 11-110. Akadémiai Kiadó, Budapest.

Spinelli G.R., Grogan Jr W.L. \& Ronderos M.M. 2009. A revision of the Patagonian predaceous midges of the genus Palpomyia Meigen (Diptera: Ceratopogonidae). Insect Systematics \& Evolution 40: 43-70. https://doi.org/10.1163/187631209X416705

Staeger R.C. 1839. Systematisk fortegnelse over de i Danmark hidtil fundne Diptera. Naturhistorisk Tidsskrift 2: 549-600.

Strobl G. 1900. Spanische Dipteren. XI. Theil. Wiener Entomologische Zeitung 19: 169-174.

Szadziewski R. 1984. Redescriptions of three species of the biting midges Ceratopogonidae (Diptera) described by Becker from Egypt. Polish Journal of Entomology 54: 183-194.

Szadziewski R. 1986. Redescriptions and notes on some Ceratopogonidae (Diptera). Polish Journal of Entomology 56: 3-103.

Szadziewski R., Dominiak P. \& Lewańczyk A. 2009. Redescriptions of Atrichopogon horni Kieffer, 1925 from Sri Lanka and Palpomyia schmidti Goetghebuer, 1934 from Iraq (Diptera: Ceratopogonidae). Polish Journal of Entomology 78: 193-199.

Szadziewski R., Gwizdalska-Kentzer M. \& Giłka W. 2011. Order Diptera, family Ceratopogonidae. In: Sheikh Tahnoon Bin Zayed Al Nahyan (patron) \& van Harten A. (ed.) Arthropod Fauna of the United Arab Emirates 4: 636-653. Dar Al Ummah Printing, Publishing, Distribution \& Advertising, Abu Dhabi, United Arab Emirates.

Szadziewski R., Borkent A. \& Dominiak P. 2013. Ceratopogonidae. In: Beuk P. \& Pape T. (eds) Fauna Europaea: Diptera Nematocera. Fauna Europaea v. 2.6.2. Available from http://www.faunaeur.org [accessed 4 Apr. 2017].

Tokunaga M. 1939. Japanese biting midges of Bezzia and Palpomyia (Ceratopogonidae, Diptera). Tenthredo 2: 273-313. 
Tokunaga M. 1966. Some nematocerous Diptera of the north-east of Afghanistan. Report of the Kyoto University Scientific Expedition to Karakoram and Hindukush 8: 273-286.

Turgut F. \& Kilic A.Y. 2015. The Ceratopogonidae (Insecta: Diptera) fauna of the Central Black Sea Region in Turkey. Turkish Journal of Zoology 39 (6): 1071-1089. https://doi.org/:10.3906/zoo-1410-33

Walker F. 1856. Insecta Britannica. Diptera. Vol. 3. Reeve and Benham, London.

Winnertz J. 1852. Beitrag zur Kenntniss der Gattung Ceratopogon Meigen. Linnaea Entomologica 6: $1-80$.

Wirth W.W. \& Ratanaworabhan N.C. 1972. Notes on the genus Macropeza Meigen and description of a new species from Florida (Diptera: Ceratopogonidae). Florida Entomologist 55: 213-217.

Zetterstedt J.W. 1855. Diptera Scandinaviae Disposita et Descripta. Vol. 12: 4547-4942. Available from http://biodiversitylibrary.org/page/9906725 [accessed 4 Aprt. 2017].

Zilahi-Sebess G. 1940. Magyarország Heleidái. Folia Entomologica Hungarica 5: 10-133.

Manuscript received: 8 February 2016

Manuscript accepted: 5 September 2016

Published on: 15 May 2017

Topic editor: Gavin Broad

Desk editor: Danny Eibye-Jacobsen

Printed versions of all papers are also deposited in the libraries of the institutes that are members of the EJT consortium: Muséum national d'Histoire naturelle, Paris, France; Botanic Garden Meise, Belgium; Royal Museum for Central Africa, Tervuren, Belgium; Natural History Museum, London, United Kingdom; Royal Belgian Institute of Natural Sciences, Brussels, Belgium; Natural History Museum of Denmark, Copenhagen, Denmark; Naturalis Biodiversity Center, Leiden, the Netherlands; Museo Nacional de Ciencias Naturales-CSIC, Madrid, Spain; Real Jardín Botánico de Madrid CSIC, Spain. 